\title{
Infrastructure Spending in China Increases Trust in Local Government
}

\author{
Bingqin Li \\ Crawford School of Public Policy, Australian National University \\ Guy Mayraz \\ Department of Economics, University of Melbourne
}

November, 1, 2015

\begin{abstract}
Following the 2008/9 financial crisis, China instituted a 4 trillion RMB stimulus package that was spent mostly on infrastructure, with a particular impact at local level. The goal was to sustain economic growth and preserve social stability. We use the Asian Barometer surveys from shortly before and after the stimulus to examine its impact on public trust in government, and find a reversal of a previous downward trend and a substantial increase in trust in local government post stimulus. We consider a number of alternative explanations for this increase in trust, and conclude that the stimulus package is the most convincing explanation. Both perceptions of corruption and experience of corruption increased over the stimulus period. Given the strong negative correlation between corruption and trust, this implies that trust would have increased even further if the level of corruption had remained the same.
\end{abstract}

JEL Classification: E62, H41, H54, I3, O53, P25, R5

Keywords: financial crisis, stimulus package, public spending, social stability, trust in government, China, infrastructure 


\section{Introduction}

Social stability is a key priority for China's government. This was made explicit in the 2004 national development strategy, aiming at promoting 'social harmony' (Cai, 2008; Delury, 2008; Smyth \& Qian, 20019). Maintaining social stability is seen to require rapid growth, but rapid growth itself involves greater income inequality within cities, rural-urban divide, predatory land acquisition, and policies favouring business interests over worker interests, all of which result in a sense of injustice, which threatens social stability (Li, 2013). Partly in order to address this threat, the government introduced a series of social policies in the 1990s and 2000s, providing social protection to the poor (Ngok, 2013), expanding social insurance, compensating those who lost land to development (Qian, 2015), and reforming the Hukou system (Cai, 2011; Zhang, 2014).

The global financial crisis was a vast new challenge to social stability. Rapid export led growth could not be sustained (Fidrmuc \& Korhonen, 2010), resulting in an estimated $7.33 \%$ decrease in GDP (Yuan, Liu, \& Xie, [2010). The danger became apparent already in 2008 when many migrant workers returned to their home villages earlier than usual at the end of the year - a sign that their employers were in trouble. In Henan Province, 60 percent of the 3.77 million migrant workers who returned to their home village for the Chinese New Year returned earlier than normal, which likely means that they have lost their job (Huang, 2010). In Chongqing, more than half of the 8 million migrants returned early (Chang \& Chen, 2010). In principal, ex-farmers who lost their city job could have returned to working the land, but many had rented their land to tenants or relatives, and could not get it back (Huang, Zhi, Huang, Rozelle, \& Giles, 2010). Moreover, many younger migrants had no real farming experience (Chan, 2010). The threat to social stability was very real.

The government initially debated whether to attempt a Keynesian stimulus, or to offer social protection to people who suffered most (Jiang, 2015). This debate ended with the government resolving to retain a minimum growth target of seven to eight percent (Kang \& Qijun, 2015) and deciding on a large scale stimulus. The immediate goal of the stimulus was to prevent a sudden slowdown in the economy, invest in public goods and services that would reduce poverty without creating dependency, sustain trust in government, and thereby preserve social stability. The stimulus package amounted to RMB4 trillion yuan, or almost $15 \%$ of GDP (Naughton, 2009). This very

large amount of money was spent primarily on infrastructure (Table $⿴$ ), and resulted in a jump in spending on infrastructure from an annual growth rate 
Table 1: The principal targets of the 4 trillion Yuan stimulus package. Source: National Development and Reform Commission (2009). http:// www.chinanews.com/cj/cj-gncj/news/2009/05-21/1702615.shtml, accessed on $31 / 7 / 2015$.

\begin{tabular}{lrr}
\hline Investment Target & $\begin{array}{r}\text { Size } \\
\text { (billion } \\
\text { yuan) }\end{array}$ & $\begin{array}{r}\text { to- } \\
\text { tal }\end{array}$ \\
& 1500 & 37.50 \\
$\begin{array}{l}\text { Major infrastructure projects such as railways, } \\
\text { highways, airports, water conservancy and upgrading } \\
\text { of urban power grids }\end{array}$ & 1000 & 25.00 \\
$\begin{array}{l}\text { Wenchuan earthquake recovery and reconstruction } \\
\text { Low-cost housing in shantytowns and other affordable } \\
\text { housing }\end{array}$ & 400 & 10.00 \\
$\begin{array}{l}\text { Innovation and industrial restructuring } \\
\text { Livelihood and infrastructure projects on rural water, } \\
\text { electricity, gas, housing }\end{array}$ & 370 & 9.25 \\
$\begin{array}{l}\text { Energy conservation and ecological construction } \\
\text { projects }\end{array}$ & 370 & 9.25 \\
Health, education, culture and other social services & 150 & 3.75 \\
\hline Total & 4000 & 100.00 \\
\hline
\end{tabular}

close to $10 \%$ just before the crisis to over $60 \%$ at the peak (Figure $\mathbb{\text { U) }}$. The 4 trillion yuan package included 1.18 trillion of direct spending by the Central Government, with the remaining money to be spent by local governments, enterprises and banks (Wong, 2001). It is estimated that the stimulus package had directly led to an increase of 4.43 percent in economic growth (Yuan et al., 2010) and rapid recovery from the initial slowdown (Zhang, 2014).

In this paper, we are interested not in the economic impact of the stimulus, but in its impact on public trust in government and social stability. The question we want to ask is: Did the stimulus achieve its social and political goals? This question is obviously interesting for understanding China, and is more broadly relevant for other countries that may experience a similar crisis. Moreover, since the stimulus was an exogenously motivated large-scale jump in local infrastructure investment, it provided a rare opportunity for studying the link between trust in government and government investment in local infrastructure. 


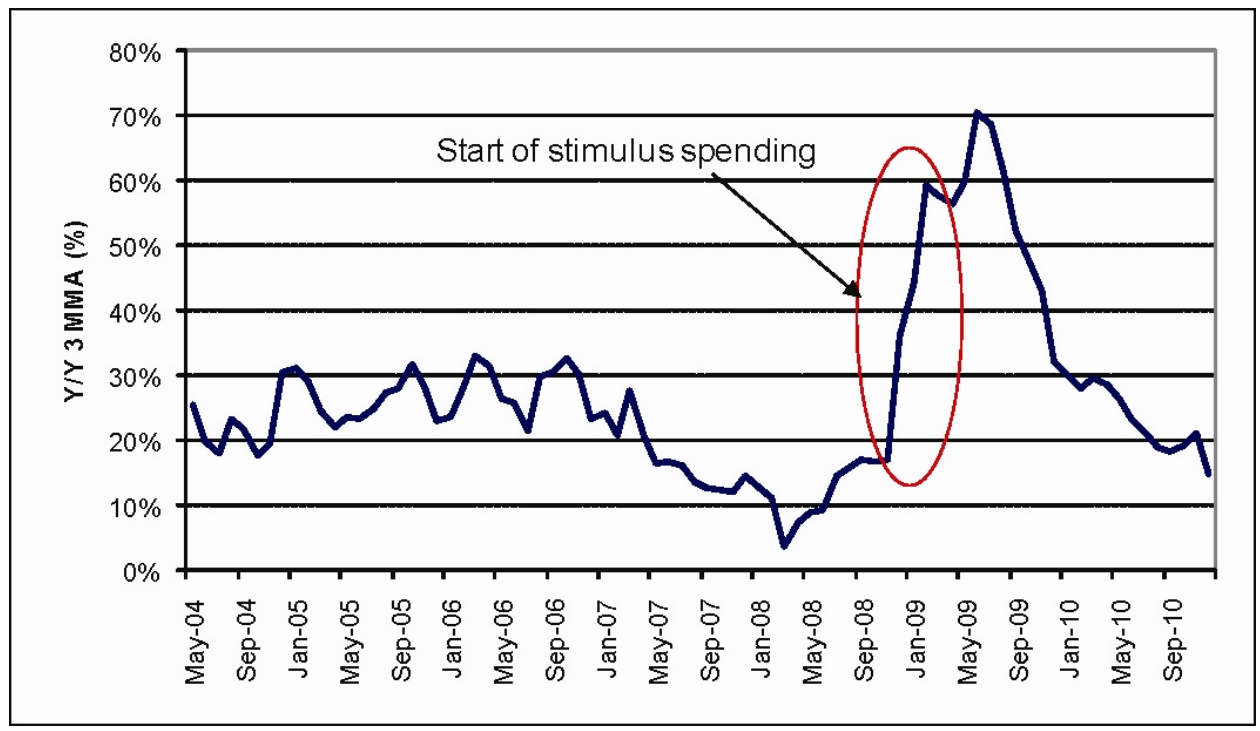

Figure 1: 3 months moving average of year on year growth in China infrastructure spending (roads, rail, waterway and ports, air transport, pipelines, post, and telecom). The stimulus involved a dramatic increase in infrastructure spending. Source: Fisher Investments, http://www.marketminder. $\mathrm{com} / \mathrm{s}$ /fisher-investments-a-q-a-on-chinas-semi-command-economy/ 34fa5af5-de5b-4ł18-91bb-870łd23560c3.aspx. Accessed on 31/7/2015. 


\subsection{Social stability and trust in government}

Trust in government increases support of government actions (Rahn \& Rudolph, 2005), improves compliance with rules and regulations, and reduces transaction costs during policy implementation (Lubell, 2007). Declining trust diminishes the legitimacy of government and undermines the rule of law (Ayres \& Braithwaite, 1992; Levi, 1998; Tyler, 2006). As events in East Europe and China in the late 1980s show, one party systems are particularly vulnerable to a low level of trust in government (Wong, 20(1).9).

China experiences a large number of public protests, each of which is a small instance of social instability (Chen, 201)9; Tong \& Lei, 2010; Göbel \& Ong, 2012). Our interest in this paper is not in these relatively isolated events, but in widespread social tensions that are bubbling under the surface, and can potentially pose a fundamental challenge to stability. We therefore focus our attention on the public trust in government, which is of interest in itself, and also serves as a proxy for underlying tensions. We use the Asian Barometer as our source for trust data, comparing trust in the 2008 wave (just prior to the financial crisis) with trust in the 2011 wave (immediately following the stimulus spending). The Asian Barometer also has useful controls, such as perceptions of local corruption and whether a respondent has directly experienced corruption.

The Asian Barometer has data on trust in both local and central government. Since most of the spending involved local government money and was used on local infrastructure, we focus our attention on whether or not the stimulus affected trust in local government. Another reason for this focus is that reported trust in national government is close to its theoretical ceiling in all three Asian Barometer waves. As can be seen in Figure \, trust in national government in the first wave was almost at the highest possible level of 4 (100\% of respondents reporting the highest possible level of trust), and even in the 2011 wave, a full $97 \%$ of respondents reported a trust level of 3 or 4. By contrast, respondents use the full scale in reporting their trust in local government, with only $20 \%$ reporting the highest level of trust. Given this difference we believe that changes in trust in local government are a more reliable measure of the public's trust in government.

\section{$1.2 \quad$ Research hypothesis}

The hypothesis we wish to test is that the stimulus has indeed increased trust in government in China. While there is no previous research on a comparable stimulus package, there are good reasons to expect such stimulus spending 


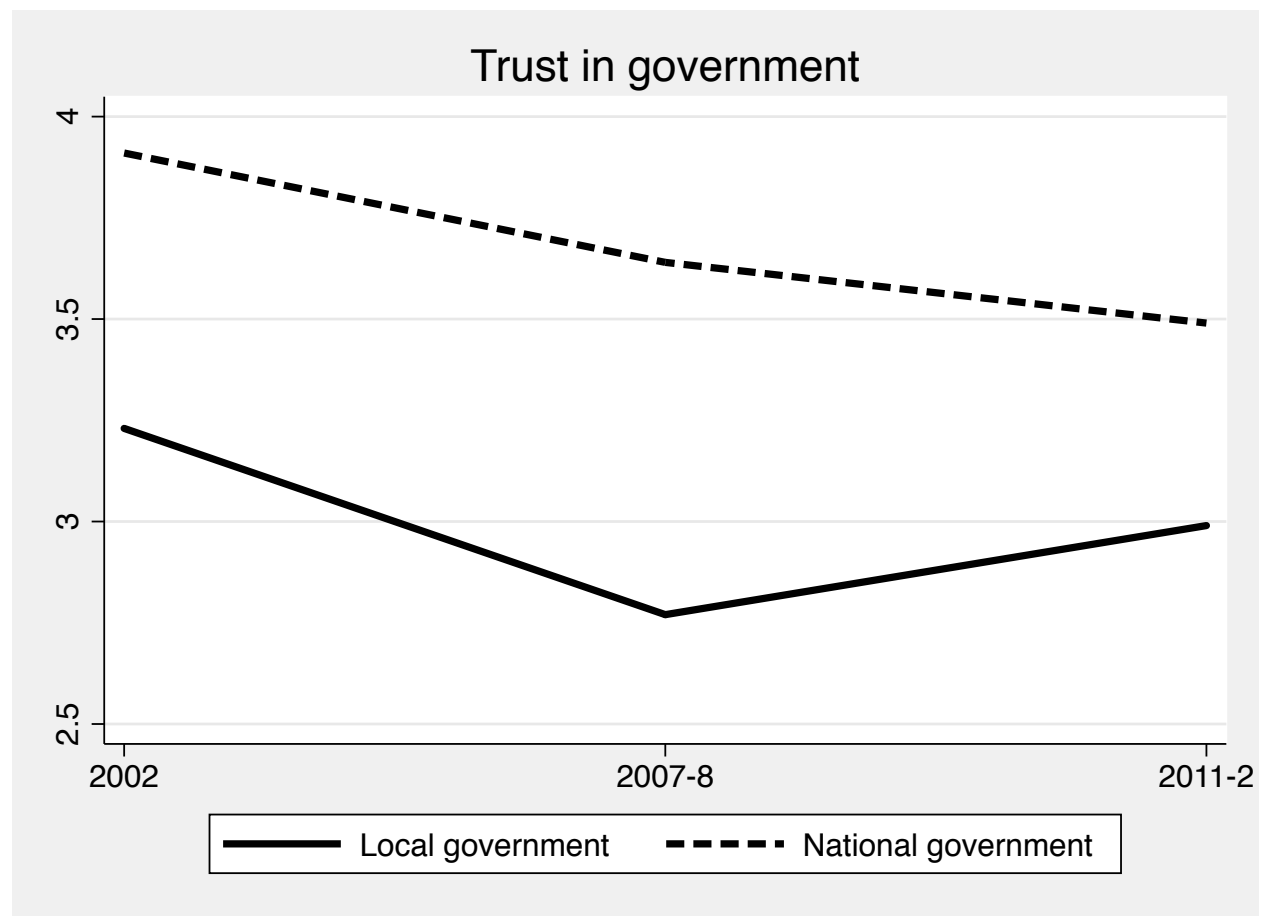

Figure 2: Trust in government in China on a 1-4 scale. Trust in local government has rebounded between 2008 and 2011, while trust in national government has continued to decline, although it remains very high. Source: Asia Barometer (2002, 2008, 2011). 
to increase trust. As Saich (2012) argues, if the leadership is seen to provide access to infrastructure and social services, this can be expected to increase trust in government. From this perspective it is important that not only has the Chinese stimulus been of unprecedented scale, the increased spending at the local and rural level has been particularly strong. Prior to the stimulus, the Chinese government was criticised for focusing on large scale projects, such as highways or high speed trains, and in rural areas villages had to count on their own resources to build poorly connected roads (Fan \& Chan-Kang, 2010.5). The stimulus package aimed at building services to benefit lower income groups and improve community based infrastructure and services, and a large part of the benefits was experienced locally and delivered locally. For example, the total length of rural roads has increased by only $3 \%$ from 2005 to 2009, but following the introduction of the stimulus it jumped by $4.5 \%$ in a single year. ${ }^{\text {W }}$ Similarly, the number of affordable houses increased dramatically, with investment by the government doubling annually in the 2008-2011 period. The government funding was matched by private sector investments, and the growth rate of affordable housing was higher than other types of houses. By the end of 2011, the proportion of affordable housing investments was 18 percent of the total investment in housing, as compared with $4 \%$ in 2008 (Zhao, 2012).

Of course, the stimulus package also had macroeconomic benefits quite apart from the improvement in infrastructure, and these may also contribute to an increased trust in government. The threat of massive unemployment was not realised, and employment increased significantly from the start of 2009 (Wong, 2011). The growth rate of the economy also recovered, and stayed above 8 per cent. According to Wen and Wang (2013) the stimulus had a multiplier effect close to or even higher than 3 at both the national and provincial level. In the absence of these macroeconomic outcomes, trust in government would likely have dropped significantly as a result of the financial crisis, as was indeed the case in many countries that did not institute a comparable stimulus package. Some authors distinguish between a competence and a goodwill aspects of trust (Kong, 201:3). Both types of trust were likely affected by the stimulus.

\subsection{Results preview}

As Figure $\square$ makes clear, trust in local government increased during the stimulus period, reversing an earlier decrease. This provides prima facie

\footnotetext{
${ }^{1}$ Source: China Statistical Yearbook 2013.
} 


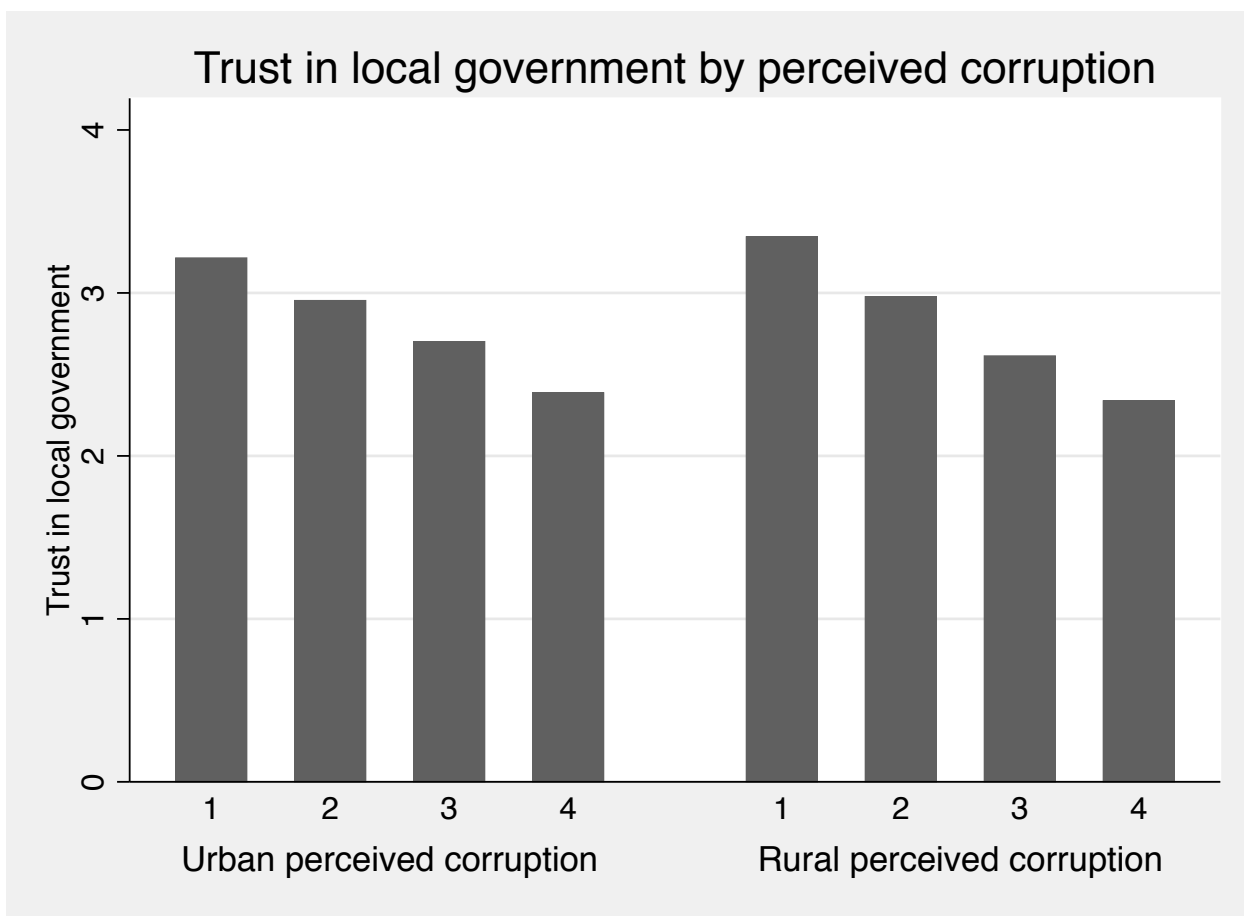

Figure 3: The cross-sectional correlation between trust in government and perceived corruption. In both rural and urban areas the two are strongly negatively correlated. Source: Asian Barometer (2008, 2011).

evidence that the stimulus has indeed succeeded in increasing trust. As we

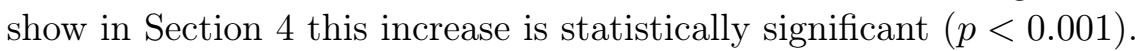

While the stimulus resulted in much needed infrastructure, it also had the less welcome consequence of increasing corruption (Wei, 2014). In the Asian Barometer data we examine, both perceived corruption and the experience of corruption increased over the stimulus period. Consistent with previous research, we find that corruption is strongly negatively correlated with trust in government in the cross-section (Figure L.3). Since trust in government increased in spite of the increase in corruption, we conclude that it would have increased even further if the level of corruption had remained unchanged.

While this paper focuses on China, it can also shed light on the relationship between trust in government and public spending more broadly. The stimulus package in China is of unprecedented size and focus, making it possible to study the impact of large scale public spending on infrastructure 
on trust in government. Moreover, in a democracy the reported trust in government often changes when the party in government changes, even if everything else remains the same (Levi \& Stoker, [2(0)(0). The absence of this factor in China is an advantage in isolating the impact of public spending. Our results suggest that governments grappling with decreased public trust in government may consider infrastructure improvements benefiting people at large as one route to restoring trust.

The reminder of the paper is organised as follows. In Section $\square$ we describe the Asian Barometer data in detail. In Section B we describe our statistical model. Section $⿴$ describes our results demonstrating the robustness of the increase in trust over the stimulus period. Section 5 considers alternative explanations of this finding, and Section [6] concludes.

\section{Data}

We use the Asian Barometer Survey (ABS). ${ }^{\llbracket}$ China was surveyed in 2002, 2008, and 2011. Our focus is on waves 2 and 3, which straddle the financial crisis and stimulus package. Wave 2 was collected just before the financial crisis in early 2008, and wave 3 just after the stimulus package in mid 2011. The number of respondents in these two waves is 5098 and 3473 respectively.

The ABS contains a set of questions on trust in institutions. Interviewees are told: "I'm going to name a number of institutions. For each one, please tell me how much trust do you have in them? Is it a great deal of trust, quite a lot of trust, not very much trust, or none at all?" The original answers are 1-4 with 1 denoting the highest level of trust. We recoded these responses, so that higher numbers denote a higher level of trust with 4 denoting the highest level.

We use the questions on trust in local government, trust in central government, and trust in political parties. While 'local government' is clearly distinct from central government, it is unclear whether respondents are thinking of their immediate region or the entire province. The question on trust in political parties obviously does not have the same meaning in China as it would have in a multi party democracy, and is likely interpreted as trust in the Communist Party. Indeed, the pairwise correlation between trust in central government and trust in political parties is as high as 0.71.

The ABS has two questions on local corruption, and we use both. One asks whether the respondent has personally experienced corruption (yes or no), and the other asks for the respondent's perception of corruption in local

\footnotetext{
${ }^{2}$ http://www.asianbarometer.org/.
} 
Table 2: Summary statistics of variables used in regressions for the observations for which all these variables are reported. Values in the 2nd and 3 rd columns are means. The 4 th column reports the pairwise correlation of each variable with trust in local government. Perceptions of local corruption and trust in national government and in the party are particularly strongly correlated with trust in local government.

\begin{tabular}{lrrr}
\hline Variable & $\begin{array}{r}\text { Pre- } \\
\text { stimulus } \\
\text { wave }\end{array}$ & $\begin{array}{r}\text { Post- } \\
\text { stimulus } \\
\text { wave }\end{array}$ & $\begin{array}{r}\text { Correlation } \\
\text { with trust }\end{array}$ \\
\hline \hline $\begin{array}{l}\text { Trust in local } \\
\text { government (1-4) }\end{array}$ & 2.66 & 2.97 & 1.00 \\
Gender (\% male) & 56.77 & 56.84 & 0.02 \\
Age (mean) & 44.85 & 44.53 & 0.11 \\
Whether own income is & 2.03 & 2.11 & 0.05 \\
sufficient (1-3) & 10.42 & 19.51 & -0.10 \\
$\begin{array}{l}\text { \% who witnessed } \\
\text { corruption }\end{array}$ & 2.45 & 2.65 & -0.33 \\
$\begin{array}{l}\text { Perceived corruption } \\
\text { (1-4) }\end{array}$ & 3.65 & 3.49 & 0.33 \\
Trust in national & & & 0.34 \\
government (1-4) & 3.62 & 3.49 & 5012 \\
\hline Trust in party (1-4) & 2475 & 2537 & \\
\hline Observations & & &
\end{tabular}

government ("Hardly anyone is involved", "Not a lot of officials are corrupt", "Most officials are corrupt", or "Almost everyone is corrupt").

The 2011 wave of the ABS has a cardinal income question that is reported for the vast majority of respondents. However, the 2008 wave only reports income for a small minority of respondents (and only by quintiles). We therefore use instead a subjective income sufficiency question, which is available for most respondents in both waves. This question asks whether income "Does not cover the needs, there are difficulties", "Covers the needs all right, without much difficulties", or "Covers the needs well, we can save".

Regressions use a balanced sample of respondents who reported answers to all the above questions, as well as gender, age, and education. Summary statistics for this sample are reported in Table $\mathbf{\nabla}$. 


\section{Model}

We assume that the underlying (latent) level of trust in local government of person $i$ is linearly dependent on whether that individual has been surveyed before or after the stimulus package, and on a number of other factors (control variables):

$$
y_{i}^{*}=\alpha+\beta d(\text { post stimulus })_{i}+\sum_{j} \gamma_{j} x_{i j}+\epsilon_{i}
$$

where $y_{i}^{*}$ is a continuous variable representing person $i$ 's underlying level of trust in local government, $d$ (post stimulus $)_{i}$ is a dummy denoting whether person $i$ was surveyed after the stimulus took effect (i.e. in the 2011 wave of the Asian Barometer, rather than in the 2008 wave), $x_{i j}$ represents the value of the $j$ 'th control for person $i$, and $\epsilon_{i}$ is the error term. Since trust in local government in the Asian Barometer is a 4 level ordinal variable, we assume that there are three cut points, such that respondents whose $y_{i}^{*}$ is above the highest cutpoint report the highest level of trust, respondents whose $y_{i}^{*}$ falls between the two highest cutpoints report the next level of trust, etc. We translate these assumptions into an ordered logit regression, which involves the further assumption that the error term has a logistic distribution. An ordered probit model which assumes a normal error distribution results in

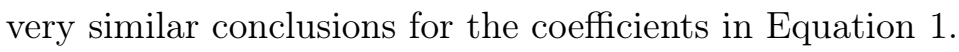

The regressor of primary interest is the dummy denoting the post stimulus period ( $d$ (post stimulus) ${ }_{i}$ in Equation $\left.\mathbb{0}\right)$, and our focus is on estimating the corresponding regression coefficient ( $\beta$ in Equation $\mathbb{0}$ ). The first specification of the model includes only this one regressor. In other specifications we gradually add the following controls: ${ }^{\text {[ }}$

1. Gender (dummy).

2. Age (numerical).

3. Education (dummy for above median education).

4. Whether the respondent's income is sufficient to cover everyday needs (3 levels).

\footnotetext{
${ }^{3}$ Section $\square$ describes these controls in detail.

${ }^{4}$ Education is reported on a scale from 2 to $10.40 .74 \%$ of the sample report education at level 4 or below, and $72.78 \%$ report education at level 5 or below. The dummy is 1 for people reporting education level 5 or higher.
} 
5. Experience of corruption (a dummy denoting whether the respondent has personally experienced corruption).

6. Perceived corruption (a 4 level ordinal variable denoting the respondent's perception of how widespread is corruption among local officials).

7. Trust in central government (a 4 levels ordinal variable with the same categories as trust in local government).

8. Trust in the party (a dummy). This variable was originally a 4 level ordinal variable, but since $94 \%$ of respondents use one of the last two categories, we combine the first two categories with the third one.

9. A dummy for whether the respondent is of pension age, defined as age 60 or above.

10. The pension age dummy interacted with the wave.

All regressions apart from the very first one include controls for gender, age, education, and income. Education can affect trust through increased contact with government officials, perhaps particularly in rural areas ( $\mathrm{Li}$, 20104). Personal income can affect trust in local government through a number of different channels. Chang and Chu (2006) argue that higher income individuals have more contact with government officials, and are more likely to experience corruption, which is likely to negatively affect their trust in government. Fang (20).9) argues that low income groups rely on local government officials for benefits, and this dependence should increase their trust in government. We include a subjective income sufficiency variable since it is the only variable available for most respondents in both waves.

Corruption measures are included as there is good evidence that perceived corruption and contacts with corrupt officials affect a persons overall perception of government (Chang \& Chu, 2006; Chu, 2013). Corruption damages trust, and the more a person deals with officials, the less they trust the government (Chang \& $\mathrm{Chu}, 20106)$. Changes in experienced and perceived corruption may thus potentially have a substantial impact on trust in local government, and can potentially provide an alternative explanation to the observed increase in trust. In our own data we find a strong negative cross-sectional correlation of -0.32 between trust in local government and perceptions of corruption (Table $\boldsymbol{Z}$ ).

\footnotetext{
${ }^{5}$ Since trust is itself a subjective variable, a case can be made for preferring a subjective measure of income in a model of trust even if an objective one were available.
} 
Trust in national government and trust in the Party are included because of potential spillover effects. Christensen and Lægreid (2005) argue that a high level of trust in one institution tends to extend to other institutions, and in this context it would not be surprising if trust in local government is affected by trust in the national government and/or trust in the Communist Party. The pension age dummy and its interaction with the wave are included to test for whether any of the increase in local trust can be explained by changes in pension policy.

Since some of the regressors are ordinal variables, we estimate two versions of the model. The first version treats all the dependent variables as cardinal, representing each by a single numerical regressor. For example, perceived corruption is represented by a number between 1 and 4 . The advantage of this approach is that it makes the relationship between trust in local government and each of the dependent variables particularly clear. Continuing the previous example, perceived corruption is strongly negative correlated with trust in local government. The second version of the model breaks down each ordinal dependent variable into a sequence of dummies. For example, perceived corruption is represented by a sequence of three dummies.

Finally, since rural and urban China are very different in their governance, we estimate these models separately in the rural and urban parts of the Asian Barometer sample. Unfortunately, we do not have the particular geographic location of individual respondents, and are therefore unable to consider differences across China other than the rural-urban split.

\section{Results}

Table $\square$ contains a summary statistics of the variables used in the regressions in the two waves we study. Note in particular that the increase in trust in local government from the 2008 wave to the 2011 wave was accompanied by an increase in corruption (personal experience of corruption and perception of corruption) and a decrease in trust in both the national government and the party. Trust in local and national government is plotted in Figure 2 .

Tables 3 and $\mathbf{6}$ show the results of estimating the first version of the model on the rural and urban samples respectively. The coefficient on the post stimulus dummy is almost identical when using the second (dummy based) version of the model, and we therefore include only these two tables in the main text. The second version of the model is available by request.

The first column of Table 3 shows that the increase in trust in local 
government in rural areas following the stimulus is highly statistically significant $(p<0.001)$ and that its magnitude is substantial: a coefficient of 2.649 in odds ratio terms. This coefficient cannot be directly compared with the difference in means reported in Table 2 . Instead, the interpretation is that, other things being equal, the odds of someone reporting a higher level on the 1-4 trust scale are 2.649 higher after the stimulus than before it.

Age, gender, and income sufficiency change little between the two waves, and the coefficient on the post stimulus wave is unsurprisingly little changed when they are added to the regression (column 2). As expected, we find that older respondents are more likely to trust the local government, and better educated respondents are somewhat less so. However, contrary to the theoretical expectation we find that more financially secure respondents are slightly more likely to trust the local government. Perhaps the reason for this finding is that sufficient income is a subjective variable that conflates actual income with a subjective satisfaction judgement that is likely to be positively correlated with trust in government. In any case, none of these factors change sufficiently over the stimulus period to have much of an effect on the coefficient on the post stimulus dummy.

An individual's experience of corruption and the perceived corruption of local officials are both strongly negatively correlated with trust in local government in the cross-section, with a pairwise correlation of -0.33 (see also Figure ‥3). Therefore, a decrease in corruption could have provided a potential explanation for the increase in trust in local government. However, both the experience of corruption and perceived corruption have actually increased over the stimulus period (Table $\mathbb{Z}$ ), so that instead of explaining the increase in trust in local government, controlling for corruption only serves to increase the coefficient on the stimulus dummy by $28 \%$ from 2.707 to 3.458 (column 3 of Table B).

We were also concerned about the possibility that trust in government increased across the board, and that trust in other institutions spilled over to trust in local government. Indeed, the pairwise correlation between trust in local government and trust in the national government is very strong $(0.33-$ similar in absolute terms to the correlation between trust in local government and perceived corruption), so that such a spillover could potentially be very significant. However, it turns out that trust in the national government and trust in the party have both decreased over the stimulus period (Table $\nabla$ ), and controlling for the two only serves to increase the coefficient on the stimulus dummy by a further $19 \%$ (column 4 of Table B).

Finally, 2009 saw the introduction of the Basic Pension System. Intended to improve the retirement of rural residents, this scheme might be expected 
to increase trust in government. However, this social insurance scheme requires most members to contribute for 15 years before becoming eligible for pension. This fact, coupled with bad memories from the failure of the rural collaborative pension scheme in the 1990s make it unlikely, in our view, that it contributed to the observed increase in trust. In order to test this, we add in column 5 a dummy for respondents of pension age (60 and over) and also its interaction with the wave. The results show that while pensioners were more trusting of the local government than younger respondents, their trust in government increased less than that of non-pensioners. This result is consistent with anecdotal reports that the introduction of the Basic Pension System was unpopular.

Table $\$$ includes the corresponding results for urban residents. The urban sample is much smaller than the rural one, so the estimates are less accurate. Overall, our results for urban residents are very similar to the corresponding results for rural residents (Table B). The coefficient on the post stimulus dummy is somewhat smaller (2.032 vs. 2.649 in the regression with no controls), but this difference disappears almost entirely when other controls are added (4.244 vs. 4.477 in column 5). In urban areas there was no particular change to the pension scheme over the stimulus period (other than a regular yearly increase of $10 \%$ that roughly matched the increase in general wages). Consistent with this, the regression in column 5 of Table $\mathbb{\theta}$ shows no particular difference in the trust of pensioners, and no difference in the trend between pensioners and younger respondents.

\section{$5 \quad$ Alternative explanations}

In Section $\square$ we find that there was a large and overwhelmingly statistically significant increase in trust in local government between the 2008 and 2011 waves of the Asian Barometer. The obvious interpretation of this increase is that it is the outcome of the 2009/10 stimulus package. In this section we consider the possibility of other factors that could provide an alternative explanation for this increase in trust.

In democracies, large scale changes in trust in government often accompany a change of government (Levi \& Stoker, 2000). In China the Communist Party has been in charge since 1949, but it would not be surprising if a change in leadership may result in a significant change in the public's trust in government. However, the same team headed by Hu Jintao and Wen Jiabao was in charge from 2002 to 2012 including the entire period we are concerned with, ruling out this alternative explanation of the change in trust. 
Table 3: Trust in local government in rural areas (compare Table $\$$ for urban areas). The table reports the odds-ratios in an ordered-logit regression of trust in local government. The cut-off points are not reported. Post-stimulus is a dummy for observations collected in 2011 after the 2009-2010 stimulus package. Controls include gender, age, education (dummy for above median education), experience of corruption (dummy), perceptions of corruption (4 levels), trust in central government (4-levels), trust in the Communist Party (dummy), and whether the respondent's income is sufficient to cover everyday needs (3 levels). The regression shows that the increase in trust following the stimulus package is robust to these controls, and indeed appears greater when these controls are included.

\begin{tabular}{|c|c|c|c|c|c|}
\hline & $\begin{array}{l}(1) \\
\text { trust }\end{array}$ & $\begin{array}{l}(2) \\
\text { trust }\end{array}$ & $\begin{array}{l}(3) \\
\text { trust }\end{array}$ & $\begin{array}{l}(4) \\
\text { trust }\end{array}$ & $\begin{array}{l}(5) \\
\text { trust }\end{array}$ \\
\hline Wave & $\begin{array}{l}2.649^{* * *} \\
(12.79)\end{array}$ & $\begin{array}{l}2.707^{* * *} \\
(13.07)\end{array}$ & $\begin{array}{l}3.458^{* * *} \\
(15.49)\end{array}$ & $\begin{array}{l}4.110^{* * *} \\
(17.08)\end{array}$ & $\begin{array}{c}4.477^{* * *} \\
(16.52)\end{array}$ \\
\hline Gender & & $\begin{array}{l}1.140 \\
(1.77)\end{array}$ & $\begin{array}{l}1.147 \\
(1.83)\end{array}$ & $\begin{array}{l}1.225^{* *} \\
(2.64)\end{array}$ & $\begin{array}{l}1.219^{* *} \\
(2.58)\end{array}$ \\
\hline Age & & $\begin{array}{l}1.009^{* * *} \\
(3.37)\end{array}$ & $\begin{array}{l}1.008^{* *} \\
(3.03)\end{array}$ & $\begin{array}{c}1.003 \\
(0.98)\end{array}$ & $\begin{array}{l}1.001 \\
(0.35)\end{array}$ \\
\hline Education & & $\begin{array}{r}0.815^{*} \\
(-2.48)\end{array}$ & $\begin{array}{c}0.803^{* *} \\
(-2.62)\end{array}$ & $\begin{array}{r}0.804^{*} \\
(-2.53)\end{array}$ & $\begin{array}{c}0.798^{* *} \\
(-2.61)\end{array}$ \\
\hline Income sufficient & & $\begin{array}{l}1.122^{*} \\
(2.45)\end{array}$ & $\begin{array}{l}1.049 \\
(0.99)\end{array}$ & $\begin{array}{r}1.057 \\
(1.10)\end{array}$ & $\begin{array}{l}1.055 \\
(1.06)\end{array}$ \\
\hline Corruption (experience) & & & $\begin{array}{l}0.693^{* * *} \\
(-3.68)\end{array}$ & $\begin{array}{c}0.719^{* *} \\
(-3.15)\end{array}$ & $\begin{aligned} & 0.713^{* *} \\
&(-3.24)\end{aligned}$ \\
\hline Corruption (perception) & & & $\begin{array}{c}0.391^{* * *} \\
(-17.38)\end{array}$ & $\begin{array}{c}0.430^{* * *} \\
(-15.16)\end{array}$ & $\begin{array}{c}0.431^{\text {*** }} \\
(-15.13)\end{array}$ \\
\hline Trust in central gov & & & & $\begin{array}{l}1.967^{* * *} \\
(7.81)\end{array}$ & $\begin{array}{l}1.974^{* * *} \\
(7.83)\end{array}$ \\
\hline Trust in Party & & & & $\begin{array}{l}1.918^{* * *} \\
(8.23)\end{array}$ & $\begin{array}{l}1.918^{* * *} \\
(8.22)\end{array}$ \\
\hline Of pension age & & & & & $\begin{array}{c}1.432 \\
(1.93)\end{array}$ \\
\hline Pension age $*$ wave & & & & & $\begin{array}{r}0.595^{*} \\
(-2.57)\end{array}$ \\
\hline Observations & 3623 & 3623 & 3623 & 3623 & 3623 \\
\hline
\end{tabular}


Table 4: Trust in local government in urban areas (compare Table 3 for rural areas). The table reports the odds-ratios in an ordered-logit regression of trust in local government. The cut-off points are not reported. Post-stimulus is a dummy for observations collected in 2011 after the 2009-2010 stimulus package. Controls include gender, age, education (dummy for above median education), experience of corruption (dummy), perceptions of corruption (4 levels), trust in central government (4-levels), trust in the Communist Party (dummy), and whether the respondent's income is sufficient to cover everyday needs (3 levels). The regression shows that the increase in trust following the stimulus package is robust to these controls, and indeed appears greater when these controls are included.

\begin{tabular}{|c|c|c|c|c|c|}
\hline & $\begin{array}{c}(1) \\
\text { trust }\end{array}$ & $\begin{array}{l}(2) \\
\text { trust }\end{array}$ & $\begin{array}{l}(3) \\
\text { trust }\end{array}$ & $\begin{array}{l}(4) \\
\text { trust }\end{array}$ & $\begin{array}{c}(5) \\
\text { trust }\end{array}$ \\
\hline Wave & $\begin{array}{l}2.032^{* * *} \\
(5.73)\end{array}$ & $\begin{array}{l}2.118^{* * *} \\
(5.85)\end{array}$ & $\begin{array}{l}2.956^{* * *} \\
(7.89)\end{array}$ & $\begin{array}{l}4.152^{* * *} \\
(9.77)\end{array}$ & $\begin{array}{l}4.244^{\text {*** }} \\
(9.16)\end{array}$ \\
\hline Gender & & $\begin{array}{l}1.281^{*} \\
(2.17)\end{array}$ & $\begin{array}{c}1.230 \\
(1.77)\end{array}$ & $\begin{array}{l}1.301^{*} \\
(2.17)\end{array}$ & $\begin{array}{l}1.306^{*} \\
(2.19)\end{array}$ \\
\hline Age & & $\begin{array}{l}1.018^{* * *} \\
(4.52)\end{array}$ & $\begin{array}{l}1.016^{* * *} \\
(3.98)\end{array}$ & $\begin{array}{l}1.011^{* *} \\
(2.74)\end{array}$ & $\begin{array}{l}1.012^{*} \\
(2.05)\end{array}$ \\
\hline Education & & $\begin{array}{r}0.916 \\
(-0.60)\end{array}$ & $\begin{array}{c}1.033 \\
(0.21)\end{array}$ & $\begin{array}{c}1.196 \\
(1.16)\end{array}$ & $\begin{array}{r}1.201 \\
(1.18)\end{array}$ \\
\hline Income sufficient & & $\begin{array}{l}1.390^{* * *} \\
(4.04)\end{array}$ & $\begin{array}{l}1.326^{* * *} \\
(3.42)\end{array}$ & $\begin{array}{l}1.260^{* *} \\
(2.67)\end{array}$ & $\begin{array}{l}1.261^{* *} \\
(2.68)\end{array}$ \\
\hline Corruption (experience) & & & $\begin{array}{c}0.648^{* *} \\
(-2.97)\end{array}$ & $\begin{array}{r}0.716^{*} \\
(-2.22)\end{array}$ & $\begin{array}{r}0.716^{*} \\
(-2.22)\end{array}$ \\
\hline Corruption (perception) & & & $\begin{array}{c}0.454^{* * *} \\
(-8.72)\end{array}$ & $\begin{array}{l}0.522^{* * *} \\
(-7.17)\end{array}$ & $\begin{array}{l}0.522^{\text {*** }} \\
(-7.17)\end{array}$ \\
\hline Trust in central gov & & & & $\begin{array}{l}1.941^{* * *} \\
(4.64)\end{array}$ & $\begin{array}{l}1.945^{* * *} \\
(4.63)\end{array}$ \\
\hline Trust in Party & & & & $\begin{array}{l}1.883^{* * *} \\
(4.71)\end{array}$ & $\begin{array}{l}1.885^{\text {*** }} \\
(4.72)\end{array}$ \\
\hline Of pension age & & & & & $\begin{array}{l}1.050 \\
(0.15)\end{array}$ \\
\hline Pension age ${ }^{*}$ wave & & & & & $\begin{array}{r}0.881 \\
(-0.39)\end{array}$ \\
\hline Observations & 1389 & 1389 & 1389 & 1389 & 1389 \\
\hline
\end{tabular}


Land grabbing in China is considered to have a big impact on trust in government, particularly in rural areas (Cui, Tao, Warner, \& Yang, 2015). Therefore, if there had been a slowdown in land grabbing, it could have perhaps provided an alternative explanation to the increase in trust in local government. However, in the period in question urbanisation continued at about same pace as before, with a $1.3 \%$ increase in the urban population every year from 2008 to 2011.

The last 20 years have seen a series of social policies that could potentially improve trust in government. In the relevant period, the most significant policy was the rolling out of health care social insurance coverage to the whole of China. However, as shown in Fang (2013b), the increased health insurance coverage failed to reduce health care costs for patients, and personal spending on health care had increased because of the higher out-of-pocket spending on prescription drugs and fees for tests. Consequently, it is hard to imagine that the health care rollout could have resulted in the increase in trust that we find.

The 2008 Beijing Olympic Games boosted national pride (Wang, 2008) and this increase in patriotism may have spilled over to an increase in trust in government. However, any such spillover should logically have resulted in an increase in national rather than local trust - it is hard to imagine why an individual living in Shanghai or Henan should come to trust the Shanghai or Henan government more because of the Beijing Olympics. Moreover, the timing is not quite right. The Beijing Olympics occurred only months after the 2008 wave of Asian Barometer was in the field (most observations were collected in January-March 2008), and could well have impacted the 2008 wave more than the 2011 wave, which was collected mostly in July 2011.

The introduction of the Basic Pension System in 2009 could potentially be seen as a possible cause of increased trust in local government. We test for this possibility in column 5 of Table 3 and find that rural pensioners' trust in local government actually increased less than that of non-pensioners. This suggests that the introduction of the Basic Pension System was unpopular, and could not explain the increase in trust. Also in rural areas we had the continuing rollout of the Rural Minimum Living Standard Guarantee, which reached 53.06 million in 2011, up from 35.66 million in 2007 (National Bureau of Statistics of China, 2014)! This again could, perhaps, be seen as a cause for increased trust in government, but we doubt this for two reasons. First,

\footnotetext{
${ }^{6}$ Source: The China Statistical Yearbook, 2014, Table 2-1.

${ }^{7}$ The relevant table is available at http://data.stats.gov.cn/easyquery.htm? $\mathrm{cn}=\mathrm{C} 01 \&$ $\mathrm{zb}=\mathrm{A} 0 \mathrm{P} 06 \& \mathrm{sj}=2014$, accessed date: $10 / 11 / 2015$.
} 
the increase in coverage over the period we study was only 17.5 million-less than $2.5 \%$ of the rural population. Second, the Minimum Living Standard Guarantee suffers from abuse by local cadres who favour their family and friends (Fang, 2013a). In fact, Li (2012) argues that its introduction only served to decrease farmers trust in local government, as it made favouritism more obvious. In any case, given the small number affected, it is unlikely that this policy has had much of an impact on the change in trust in local government over the stimulus period.

\section{Conclusion}

When the 2008 financial crisis hit China, the government decided on a massive 4 trillion RMB stimulus to prop up the economy, invest in local infrastructure, and prevent a rise in social instability and a collapse in public trust. We examine two waves of the Asian Barometer collected shortly before the crisis in early 2008 and shortly following the stimulus package in 2011, and find a large and strongly statistically significant increase in public trust in local government. This increase is particularly striking given that trust has decreased significantly between the 2002 and 2008 waves. We investigate a number of alternative explanations, and conclude that none of them provides a plausible explanation for the observed increase in trust. We thus conclude that the stimulus package has indeed succeeded in its aim of shoring up public trust in government.

The stimulus was not without negative consequences. Wei (2014) claimed that the stimulus resulted in an increase in corruption, and we indeed find an increase in perceived corruption and personal experiences of corruption over the stimulus period. Corruption is strongly negatively correlated with trust in our data, and we estimate that the increase in corruption substantially limited the improvement in trust.

There was no change in leadership throughout the stimulus period. This political stability combined with the very large scale of the stimulus provide a natural experiment for the impact of infrastructure investment on public trust. The experience of China in this period suggests that infrastructure investments (particularly at the local level) are an effective means for increasing public trust in government. This is likely to be particularly important in countries where access to basic infrastructure is not yet available to a significant proportion of the population.

Not all government investment is likely to have the same impact on trust. It is when the spending is socially beneficial and actually reaches the dis- 
advantaged population that trust in government is most likely to increase, at least in the level of government that is directly responsible to delivering the investment. Any increase in perceived corruption that accompanies the increased investment is bound to work against the increase in trust, but the net effect may still to be positive. Western democracies are obviously very different, but the same principles may still be relevant.

Our results suggest that the stimulus was successful in preventing a further decrease in trust that could have ended in substantial social instability. Indeed, the downward trend was reversed, and trust went up. This emergency measure is, however, clearly not a long-term solution. The stimulus required an investment level that could not be sustained over an extended period, and had many negative consequences, such as price inflation, a large increase in local government debt, and over production in some industrial sectors (Wei, 2014; Jiang, 2015). While a Keynesian stimulus can be an effective response to a short term crisis, other measures are required for structural problems, such as the recent decrease in China's growth rate. A short term stimulus is also bound to have only a short term impact on trust, and other more sustainable reforms may be required to retain trust in government for the long term. Reducing the perception of endemic corruption, improving political representation, and enhancing transparency of government (Toffler, 2014), may all be indispensable to sustaining trust in the future.

\section{References}

Ayres, I. \& Braithwaite, J. (1992). Responsive regulation: transcending the deregulation debate. Oxford University Press.

Cai, F. (2011). Hukou system reform and unification of rural-urban social welfare. China \&s World Economy, 19(3), 33-48.

Cai, Y. (2008). Social conflicts and modes of action in china. The China Journal, 89-109.

Chan, K. W. (2010). The global financial crisis and migrant workers in China: 'There is no future as a labourer; returning to the village has no meaning'. International Journal of Urban and Regional Research, 34(3), 659-677.

Chang, E. C. \& Chu, Y. (2006). Corruption and trust: exceptionalism in asian democracies? Journal of Politics, 68 (2), 259-271.

Chang, Y. \& Chen, R. (2010). An empirical study of criminal offences of returning migrant workers in chongqing city (chóngqìng shì huíliú nóngmín gng fànzuì shízhèng yánji). Frontiers (qianyan), 8, 93-96. 
Chen, C. J. (2009). Growing social unrest and emergent protest groups in china. Rise of China: Beijing's strategies and implications for the AsiaPacific, 87-105.

Christensen, T. \& Lægreid, P. (2005). Trust in government: the relative importance of service satisfaction, political factors, and demography. Public Performance \& Management Review, 28(4), 487-511.

Chu, Y.-h. (2013). Sources of regime legitimacy and the debate over the chinese model. China Review, 13(1), 1-42.

Cui, E., Tao, R., Warner, T. J., \& Yang, D. L. (2015). How do land takings affect political trust in rural china? Political Studies, 63(S1), 91-109.

Delury, J. (2008). "harmonious" in china. Policy Review, 148, 35.

Fan, S. \& Chan-Kang, C. (2005). Road development, economic growth, and poverty reduction in china. Intl Food Policy Res Inst.

Fang, F. (2013a). Fairness and justice of the rural minimum living standard guarantee system. realistic (nongcun dibao zhidu de gongping zhengyi wenti tantao). Truth Seeking (qiushi), 1, 91-93.

Fang, L. (2009). Formation of institutional truststhe case of new rural cooperative healthcare (zhidu xinren de xingcheng guochengyi xinxing nongcun hezuo yiliao zhidu weili). Sociology Studies (shehuixue yanjiu), 2.

Fang, L. (2013b). China's health reform and development report. In P. Li, G. Chen, \& Y. Zhang (Eds.), 2014 china social situation analysis and prediction (pp. 90-105). Social Sciences Academic Press.

Fidrmuc, J. \& Korhonen, I. (2010). The impact of the global financial crisis on business cycles in asian emerging economies. Journal of Asian Economics, 21 (3), 293-303.

Göbel, C. \& Ong, L. H. (2012). Social unrest in china. Long Briefing, Europe China Research and Academic Network (ECRAN).

Huang, H. (2010). Entrepreneurship among returning henan migrant workers (hénán shng hui xing nóngmín gng chuàngyè wènti yánji) (Doctoral dissertation, Henan Agriculture University).

Huang, J., Zhi, H., Huang, Z., Rozelle, S., \& Giles, J. (2011). The impact of the global financial crisis on off-farm employment and earnings in rural china. World Development, 39(5), 797-807.

Jiang, Y. (2015). Vulgarisation of keynesianism in china's response to the global financial crisis. Review of International Political Economy, 22(2), 360-390.

Kang, C. \& Qijun, L. (2015). Economic development and corruption in china in the shadow of rent. In R. D. Congleton \& A. L. Hillman (Eds.), Com- 
panion to the political economy of rent seeking (pp. 395-409). Edward Elgar.

Kong, D. T. (2013). Intercultural experience as an impediment of trust: examining the impact of intercultural experience and social trust culture on institutional trust in government. Social indicators research, 113(3), 847-858.

Levi, M. (1998). A state of trust. Trust and governance, 1, 77-101.

Levi, M. \& Stoker, L. (2000). Political trust and trustworthiness. Annual review of political science, 3(1), 475-507.

Li, B. (2013). Future trajectories for china. In J. Midgley \& D. Piachaud (Eds.), Social protection, economic growth and social change (pp. 5976). Edward Elgar Publishing.

Li, H. (2012). Rural residents trust of the rural minimum income guarantee system (nongcun jumin dui nongcun dibao zhidu de xinren yanjiu) (Master's thesis, Central Agriculture University).

Li, L. (2004). Political trust in rural china. Modern China, 30(2), 228-258.

Lubell, M. (2007). Familiarity breeds trust: collective action in a policy domain. Journal of Politics, 69(1), 237-250.

National Bureau of Statistics of China. (2014). China statistical yearbook.

Naughton, B. (2009). Understanding the chinese stimulus package. China Leadership Monitor, 28(2), 1-12.

Ngok, K. (2013). Shaping social policy in the reform era in china. In M. Izuhara (Ed.), Handbook on east asian social policy (pp. 105-125). Edward Elgar Publishing.

Qian, Z. (2015). Land acquisition compensation in post-reform china: evolution, structure and challenges in hangzhou. Land Use Policy, 46, 250257.

Rahn, W. M. \& Rudolph, T. J. (2005). A tale of political trust in american cities. Public Opinion Quarterly, 69(4), 530-560.

Saich, A. (2012). The quality of governance in china: the citizen's view. Harvard University, John F. Kennedy School of Government.

Smyth, R. \& Qian, J. X. (2009). Corruption and left-wing beliefs in a postsocialist transition economy: evidence from china's "harmonious society". Economics Letters, 102(1), 42-44.

Toffler, A. (2014). Learning what makes government work in the 21st century. In J. Z. K. Zubair K. Bhatti \& T. Verheijen (Eds.), Logged on: smart government solutions from south asia (Chap. 2, pp. 28-57). World Bank.

Tong, Y. \& Lei, S. (2010). Large-scale mass incidents in china. East Asian Institute, National University of Singapore. 
Tyler, T. R. (2006). Why people obey the law. Princeton University Press.

Wang, Z. (2008). National humiliation, history education, and the politics of historical memory: patriotic education campaign in china. International Studies Quarterly, 52(4), 783-806.

Wei, S. (2014). The logic (or illogic) of china's local government debts out of control-law, governance or other perspectives. Governance or Other Perspectives (January 12, 2015), 44(3), 887-916.

Wen, Y.\& Wang, X. (2013). Multiplier effects of government spending: a tale of china. In 2013 meeting papers (214). Society for Economic Dynamics.

Wong, C. (2009). Rebuilding government for the 21st century: can china incrementally reform the public sector? The China Quarterly, 200, 929952.

Wong, C. (2011). The fiscal stimulus programme and public governance issues in china. OECD Journal on Budgeting, 11(3), 1-22.

Yuan, C., Liu, S., \& Xie, N. (2010). The impact on chinese economic growth and energy consumption of the global financial crisis: an input-output analysis. Energy, 35(4), 1805-1812.

Zhang, Z. (2014). Diminishing significance of hukou and decline of ruralurban divide in china's social policy reforms. Transforming Chinese Cities. London: Routledge, 15-30.

Zhao, P. (201217). Affordable housing effectively increase the housing supply (bozhàng fáng yuxiào zngjile zhùfáng gngj). China Information News (Zhngguó xìnx bào). 